UDC 371.38:377.169.3

\author{
Ruslan V. Kuzmenko \\ $\mathrm{PhD}$ of Technical Sciences, Deputy Chief of Combat Vehicle Driving Department \\ Hetman Petro Sahaidachnyi National Army Academy, Lviv, Ukraine \\ ORCID 0000-0003-3452-725X \\ kuru1978@gmail.com
}

\title{
ADAPTIVE DRIVER TRAINING WITH THE USE OF SIMULATOR SYSTEMS
}

\begin{abstract}
The article looks at certain aspects of using automated information systems in the professional training of drivers at Hetman Petro Sahaidachnyi National Army Academy, Ukraine. The importance of integrating the theoretical and practical components of learning and the linkage between learning outcomes and safety on the roads are emphasized. The modern educational-training equipment for training drivers (simulators) includes information program components that can be customized to suit students' individual characteristics and priorities for consideration in real roadtraffic conditions. Assessment of students' knowledge and skills with simulators is carried out by analyzing their errors on typical routes that simulate problematic traffic situations. The main types of errors correspond to the common causes of road-traffic accidents, in relation to which statistics according to regions and periods are available, which, while training, gives a possibility to quickly respond to changes in the structure of accidents in the recent years in view of their causes. The automated information system is configured by a teacher in the way of correction of penalty points for every type of error. Upon reaching the critical amount of such points, the student is directed to retake the course, which makes it possible to provide the proper level of mastering the material before starting classes in the conditions of a real road situation. In future, increasing the share of the training time on the stimulator, it will be possible to take into account the students' individual features of assimilating the material. This can be realized by introducing increased coefficients for repetitive errors into the penalty function. For this purpose a linear model of the total penalty score is proposed in the paper, which takes into account the specific and general errors, moreover, in the latter the base price of the error is related to the share of accidents with severe consequences. The multiplier of the individual weight of the error allows increasing its value in case this type of mistake occurred earlier and the student did not heed it.
\end{abstract}

Keywords: automated information systems; vehicle driver training; educational-training equipment; learning outcomes assessment; traffic rules.

\section{INTRODUCTION}

Formulation of the problem: Insufficient professional skills of drivers can lead to severe consequences and nowadays it is one of the main causes of road accidents. The analysis of a road-traffic accident shows that the wrong and uncoordinated actions in most cases are due to mistakes in the assessment of road transport situations and prediction of their further development [1]. One of the ways to reduce mistakes while driving is to increase the professional skill of the driver and to form and consolidate the skills of operational analysis of the road transport situations. The principal approach to skill development is practical training and consolidation of the acquired driving skills with the use of training equipment and automated information systems of driver training (hereinafter - AIS).

Simulators cannot completely replace real driving practice, but they have a number of significant benefits, including safety of training, economic effect and versatility. The latter includes the ability to model a wide range of road conditions; flexibility and adaptability, namely 
the ability to conduct learning based on the individual features of the students and their ability to evaluate the traffic situation. Such estimation should be based on the capabilities of specific types of simulators and take into account the potential complexity of individual traffic situations and the risk of road accidents that could result from them.

The mechanisms of such estimation are not sufficiently studied, and the use of data on accident statistics along with a flexible algorithm to take into account peculiarities of acceptance by the trained person will help to increase the efficiency of training.

Analysis of recent research and publications. With the expansion of the nomenclature of technical means of training and a more comprehensive involvement of computer technology and elements of information systems, the volume of research on the study of the use of training equipment and its elements in the training of drivers is increasing.

In the works [2], [3], [4] the expediency and peculiarities of the use of modern information technologies in the training of drivers of motor vehicles with the use of training equipment, in the Armed Forces of Ukraine in particular, were studied. Papers [5], [6], [7] consider some important results from foreign research.

Training with the use of information and communication technologies allows providing elements of an individual approach to learning and creates conditions for the formation of independence, the ability to adapt in a rapidly changing environment. The capabilities of the flexible configuration of the software unit of a simulator complex are not always used to the full and with maximum orientation towards the quality of training. The analysis of the quality and adjustment of technical equipment, in particular stimulators, often play a key role in consolidating theoretical knowledge and improving drivers' practical skills, which are a key to ensuring traffic safety.

Recently, the problem of traffic safety has acquired national importance [1], and the available statistics [8], [9] demonstration a large number of material and human losses. At the same time road accident statistics is recorded according to regions, complexity, and type of adventures, etc.

The aim of this article is to conduct an analysis of application of automated training systems (simulators) as an element of drivers' practical training based on the training devices ATK-3UE adopted in the Armed Forces of Ukraine and to develop ways of its improvement, taking into account the recent changes in accident statistics and the peculiarities of the individual perception and consolidation of the training material.

\section{THE RESULTS AND DISCUSSION}

General characteristics of the driver training system. Considering the existing driver training system, it can be noted that it involves mastering theoretical and practical components.

The practical component according to [10] includes 60 hours of practical driving and is distributed between driving instruction on a car simulator and real driving practice in various road conditions.

An important aspect in the training of a professional driver is a technique for evaluating the execution of practical exercises. Based on the training system, the process of evaluating practical skills and abilities occurs both automatically, during the exercise on a car simulator, and by means of subjective evaluation by an instructor during real driving. And it is the correspondence between the system of automated evaluation and practical indicators which is of paramount importance. 
The armaments of the Armed Forces of Ukraine include a collection of ATK automobile training complexes produced by Research and Production Enterprise "Metekol".

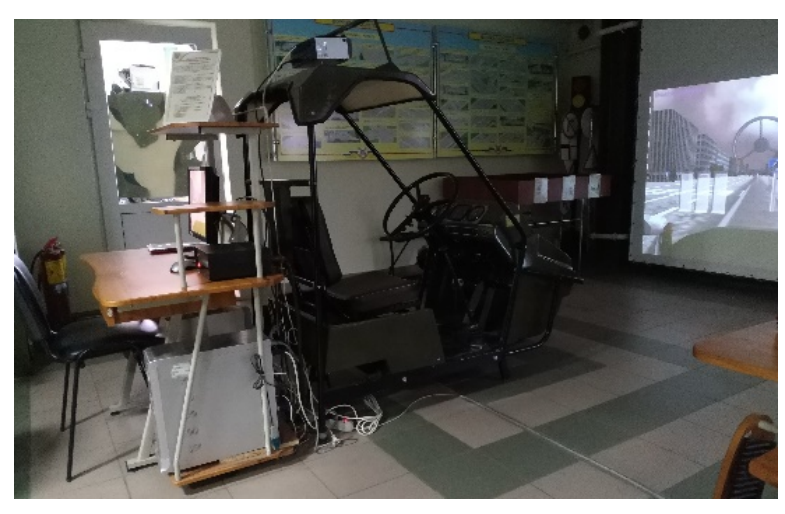

a) $A T K-3.00 U E$

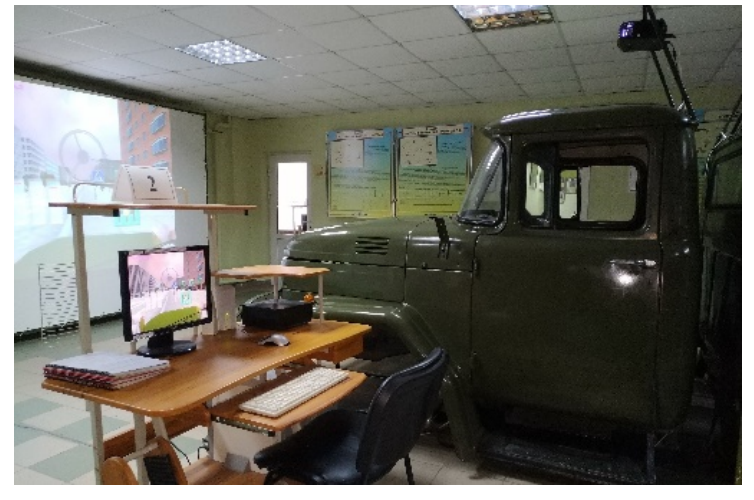

б) $A T K-3.10 U E$

Fig. 1. Education and training facilities for drivers produced by the Scientific-Production Enterprise "Metekol"

The developers of this collection of simulators have installed a rating system, which in general consists of common errors (arising in case of violation of traffic rules) and mistakes that arise during the process of driving.

The first group includes 12 mistakes that may be allowed for reasons that are connected with insufficient knowledge of traffic rules, as well as the inability to evaluate the road transport situation as a whole, when performing specific maneuvers, etc.

Another group of mistakes is the errors that the system fixes in the process of controlling a specific mode of transport and associated with the design features of cars ("not enough pressed accelerator pedal", "speed does not correspond to the included transmission" "movement with a locked differential in normal road conditions" and others), their number is 33 errors. The registration of this group of errors ensures that the level of student's mastering the practical skills in driving a car and the ability to maintain it in a proper technical condition is checked.

Set-up of the automated evaluation system of the simulator. The assessment of the level of training of the person undergoing training on these simulators is carried out with the calculation of penalty points for certain types of errors. The setting of the parameters of the assessment system is done directly by the teacher (instructor) with the help of the corresponding elements of the system interface. In the "Evaluation system" dialog box, the number of points that are valid for the grades "5", "4" and "3" is determined. The window shows the list of errors for the selected group and the "weight" of each of them, while the error weight can be edited (Fig. 2). 

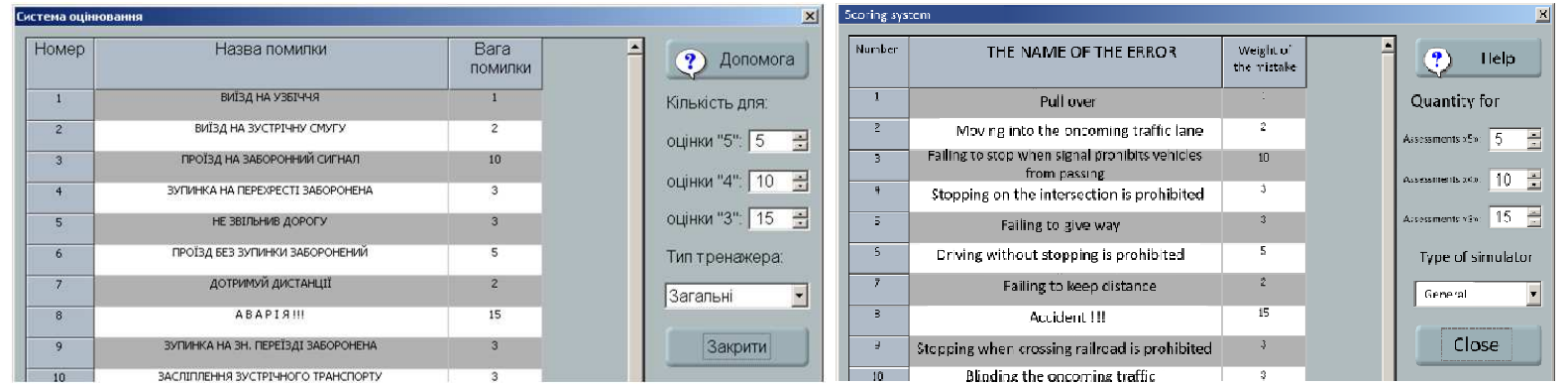

Fig. 2. A fragment of the ATK-3UE simulator configuration dialog box (left:original, right:English version)

From the point of view of information technologies and systems, the technical means of training and control of drivers are implemented in the form of AIS simulator [11], which both allows driver training and provides an opportunity to check and control the students' performance.

In general, while working with the simulator, two types of interfaces are used: the first one is used by the trainee - this interface should simulate the conditions of the DTS as precisely as possible (Fig. 3); the teacher (instructor) uses the other one when setting up a training complex (Fig. 4).

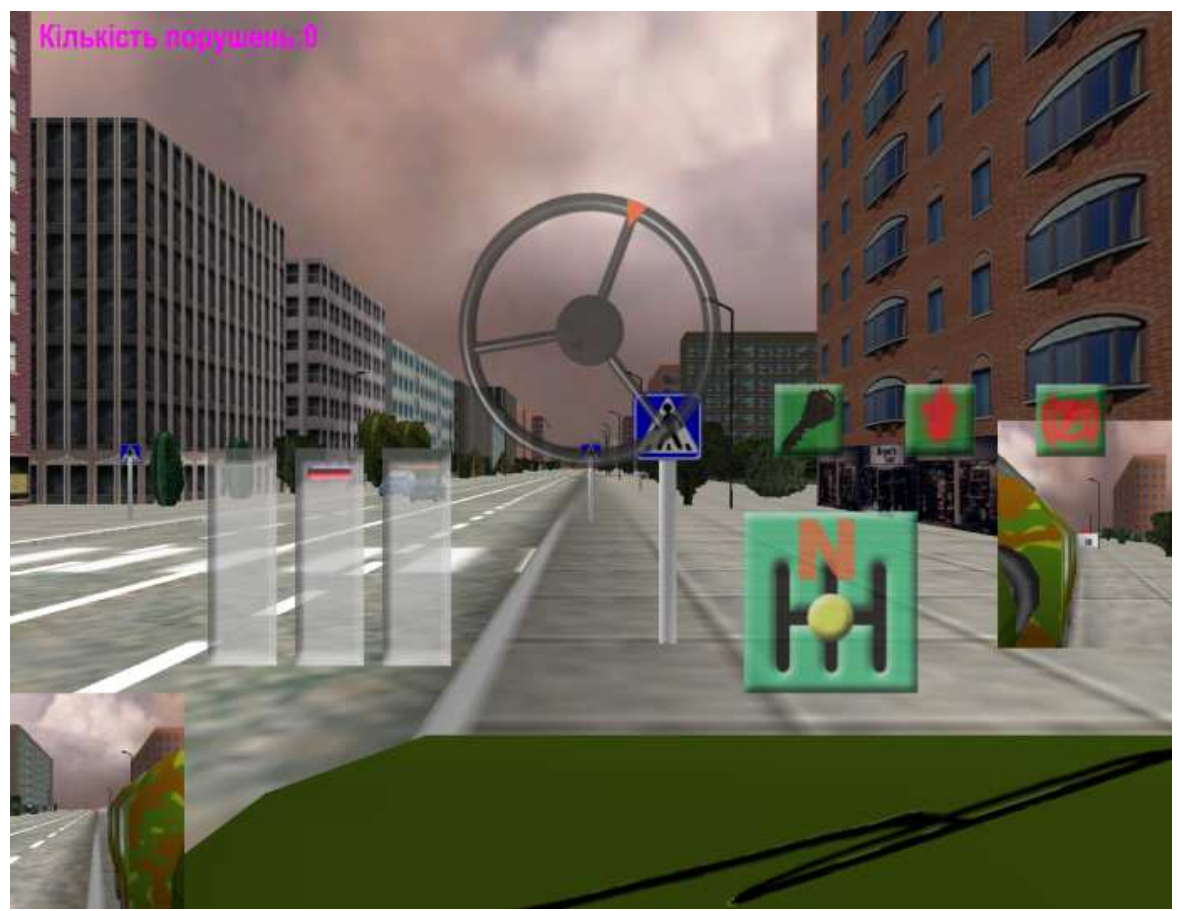

Fig. 3. User's window of the exercise 

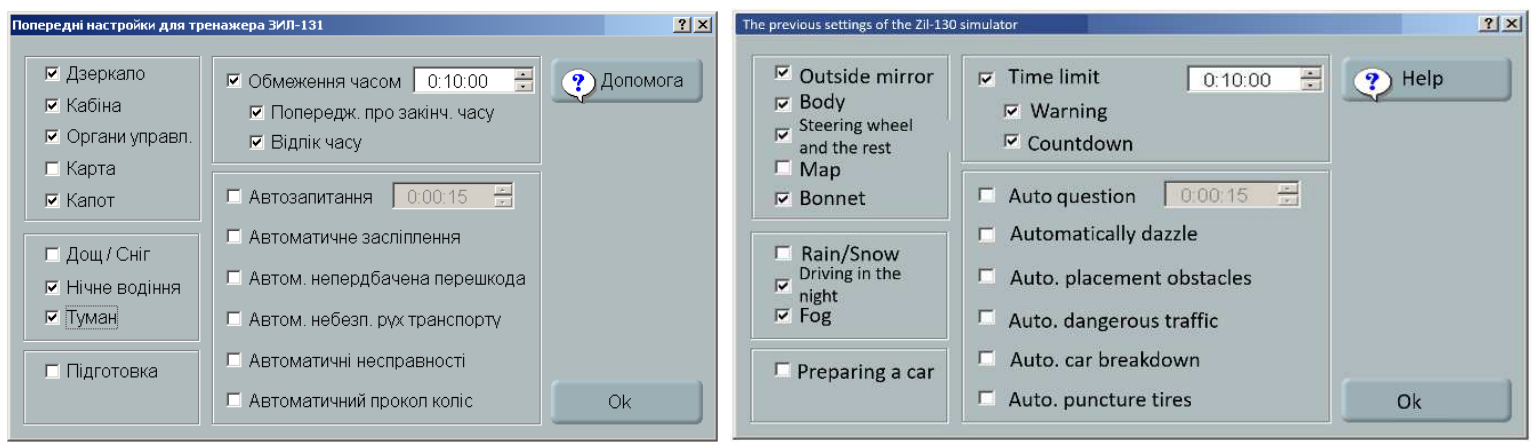

Fig. 4. Exercise setting dialog box (left:original, right:English version)

Another structural element of the AIS is a database containing a variety of information, including patterns of correct actions and errors in testing, which in turn allows tracking the progress of learning the material by a particular student for the chosen period of study.

In the modern AIS there are databases that increasingly acquire the features of knowledge bases [12]. In the learning process a properly configured simulator should ensure the consistency, reliability and thoroughness of knowledge and skills. The formation of situations involving the consolidation of knowledge of the traffic rules should not literally follow their order, listed in [13], but should ensure the formation of a logically related and consistent system of knowledge of the traffic rules, basic driving skills, the ability to handle road transport situations, effectively respond to their change, etc.

The formation of a holistic system of knowledge, skills and abilities implies that the main goals (to achieve which the selection of elements of the knowledge base of the AIS simulator is carried out) include:

- full coverage of traffic rules;

- flexible modeling system of the road transport situation (the algorithms of which provide different levels of complexity and account for frequencies of situations associated with road accidents);

- the modeling system of the car motion, proceeding from the model of road transport situation in problem situations.

However, it is also important that:

- the presentation and consolidation of the material proceed gradually, from simple to complex;

- individual peculiarities of the perception (assimilation) of the material and acquiring practical skills be taken into account;

- special attention be paid to the most important moments - the analysis of problem situations in which the most frequent accidents occur.

Given the above, it is advisable to consider the latter requirement in more detail. For this purpose, we will conduct a comparative analysis of violations that are the cause of the road accident, and violations that are distinguished and revealed by the AIS simulator as driving errors.

Violations of traffic rules that cause accidents. The Road Traffic Safety Administration [8] provides accident statistics both in Ukraine as a whole and in certain areas, as well as in categories, in particular:

Accidents with severe consequences (total number, deceased and injured persons); 
Accidents with casualties by type (rear-end collision, rollover, collision with a vehicle or an obstacle, collisions involving pedestrians and cyclists, and other types of road accidents);

Accidents with casualties due to the causes (the fault of drivers, pedestrians, children; unsatisfactory road condition; unsatisfactory state of streets; due to the bus drivers; due to the fault of drivers of a technically defective vehicle).

Source [9] gives information on the number of accidents involving injured (wounded) and deceased in the Lviv region. The analysis shows that the total number of accidents is increasing: in 2000-2002 the number of accidents with casualties in the region was about 1,3 thousand, during the next five years this number doubled, in 2007-2010 there was a definite tendency towards their decrease - down to 1.6 thousand and this number stays up to this day.

Approximately the same situation is in Ukraine as a whole (Fig. 5). So, in 2018 in the country there were 150120 accidents, including 24294 accidents with casualties. In these accidents 3350 people died and 30884 people were injured. According to the Information and Analytical Support Department [8], 40\% of accidents are car collisions, 31\% - collisions with pedestrians, $12 \%$ - collisions with obstacles, collisions with cyclists and rollovers make up $7 \%$ of all accidents with victims (Fig .6).

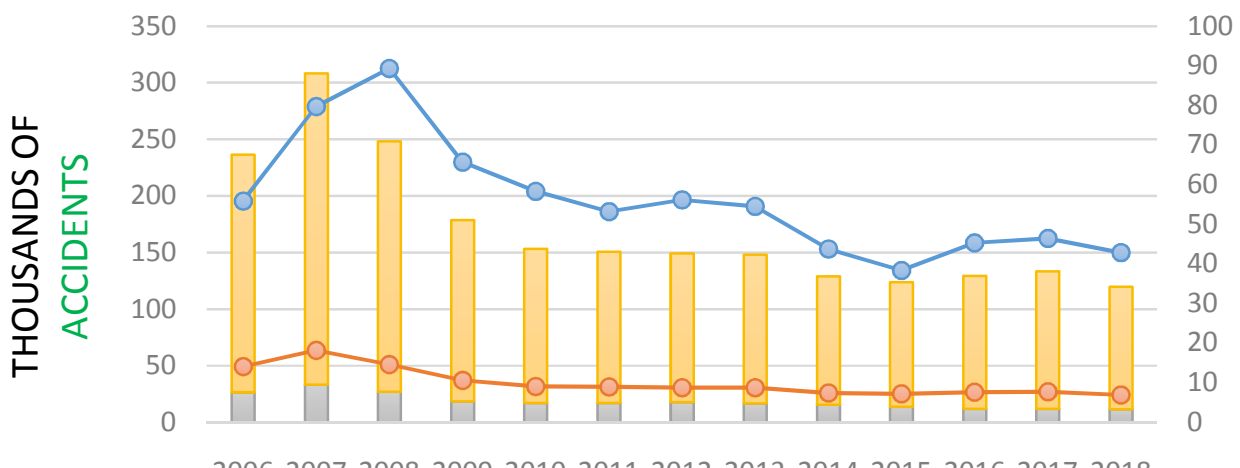

2006200720082009201020112012201320142015201620172018

died - among the victims $\square$ injured-among the victims

$\rightarrow$ - traffic accidents- in total $\quad \longrightarrow$ - traffic accidents with victims

Fig. 5 Road accidents and resulting casualties in Ukraine from 2006 to 2018 


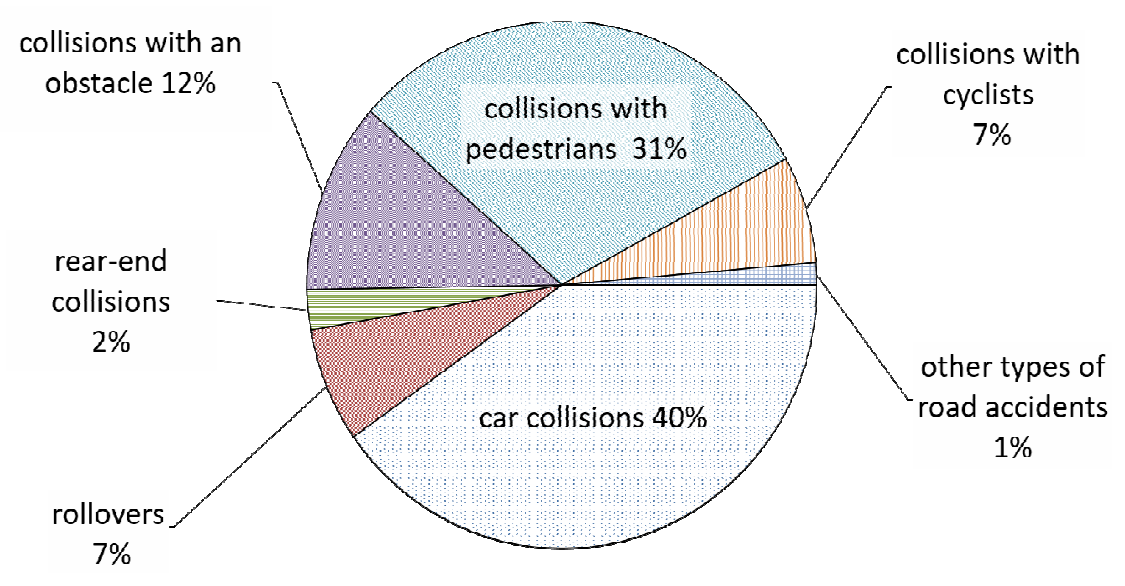

Fig. 6 Road accidents with casualties classified by type for the period from 01.01.2017 to 31.08.2017

Among the causes of road accidents with casualties, seven factors are prevalent (counting up to $84 \%$ of all accidents) [8]:

- exceeding of safe speed $29 \%$;

- violation of maneuver rules $15 \%$;

- drunk driving 14\%;

- violation of traffic rules at the intersections $9 \%$;

- non-keeping the distance 7\%;

- violation of road crossing rules by pedestrians $5 \%$;

- moving into the oncoming traffic lane $5 \%$.

As it can be seen, actions of the driver are the key factor that the road safety depends on. Violation of maneuver rules, non-observance of rights of way at junctions, pedestrian crossings and rail crossings, also violating rules for overtaking, stops and parking (totaling $30 \%$ of accidents) indicate low discipline and / or driver qualifications; moving into the oncoming traffic lane, non-keeping the distance, exceeding the set and safe speed (together $42 \%$ of accidents) indicate lack of experience and again the need for advanced training of drivers. This problem can be partially solved by improving the driver training system.

Also, the causes of road accidents through the drivers' fault [14] include: heavy braking on the slippery section of the road, violation of the rules of transit of public transport stops, rules of stacking and carriage of goods, wrong choice of interval, driving a technically defective car, driver's blinding by the light of the headlights of the oncoming car. Simulation of most of the above situations is, to a greater or lesser extent, incorporated into the work of the training complex, except for one that is not subject to correction - drunk driving, and a few minor offences, such as violation of the traffic rules by ridden or herded animals $(0,02 \%$ of accidents with casualties), violations of the rules of maintenance of motorways and streets $(0.06 \%)$, exhaustion, falling asleep while driving $(0.51 \%)$.

Correspondence between the settings of the AIS simulator and the actual state of accident frequencies on the roads of Ukraine. Table 1 shows the correspondence between typical and most common mistakes and their consideration in the work of the ATK 3UE 
simulator. It is important to mention that any violation which may lead to an emergency is fixed by the stimulator as a gross violation and is classified as violation No. 9 "ACCIDENT".

\section{Correspondence between the causes of the accident and errors that are fixed by the AIS simulator}

\begin{tabular}{|l|l|}
\hline $\begin{array}{c}\text { The main causes of accidents through the driver's } \\
\text { fault according to statistics [8] and literature [14] }\end{array}$ & $\begin{array}{c}\text { General and special errors that are recorded and } \\
\text { evaluated by the AIS simulator }\end{array}$ \\
\hline Exceeding the safe speed & $\begin{array}{l}\text { №1 "Moving along the roadside" } \\
\text { №3 "Failing to stop at a stop sign" } \\
\text { №5 "Driving without stop is forbidden" } \\
\text { №6 "Driving through closed barrier" } \\
\text { №7 "You had to clear the road" }\end{array}$ \\
\hline Violation of maneuver rules & $\begin{array}{l}\text { №2 "Moving into the oncoming traffic lane" } \\
\text { №4 "Stop at the intersection is prohibited" } \\
\text { №7 "You had to clear the road" }\end{array}$ \\
\hline $\begin{array}{l}\text { Von-keeping the distance and wrong choice of the } \\
\text { interval }\end{array}$ & №8 "Keep the distance" \\
\hline Violation of road crossing rules by pedestrians & $\begin{array}{l}\text { №3 "Failing to stop at a stop sign" } \\
\text { №5 "Driving without stop is forbidden" }\end{array}$ \\
\hline Moving into the oncoming traffic lane & №2 "Moving into the oncoming traffic lane" \\
\hline Driving a technically defective car & $\begin{array}{l}\text { №38 "The tire pressure does not match the type of } \\
\text { terrain" } \\
\text { №44 "Low oil pressure! Seized engine!" } \\
\text { №45 "High temperature! Engine overheating!" }\end{array}$ \\
\hline Violation of the rules of transit of public transport stops & $\begin{array}{l}\text { №5 "Driving without stop is forbidden" } \\
\text { №7 "You had to clear the road" }\end{array}$ \\
\hline $\begin{array}{l}\text { Driver's blinding by the light of the headlights of the } \\
\text { oncoming car }\end{array}$ & №10 "Blinding by the light of the oncoming vehicle" \\
\hline
\end{tabular}

When preparing drivers, it is necessary to pay attention to the actual state of violations on the roads and to focus the training emphasis on avoiding the most dangerous mistakes. This can be achieved by selecting the penalty coefficients of the AIS simulator in such a way as to stimulate the learner to pay more attention to situations and circumstances that may lead to accidents with severe consequences. In the simplest model, penalty points (B) can be selected proportional to the proportion of violations (x) given in Fig. 6 or more precisely in the data of accident statistics [8]. In this case, the use of the linear model $(B=k * x)$ is limited by a significant spread of absolute values, therefore it is more appropriate to use a log-scale that will allow somewhat smoothing the spread in the number of violations (eg in the form $\mathrm{B}=\log _{2}(1+\mathrm{k}$ $* \mathrm{x})$ ).

If while testing we take into account penalty points in proportion to the weight of the violation (how often this violation causes an accident), it is worth using the relative scales. In this approach, the errors that are fixed by the AIS simulator and which do not belong to the main causes of accidents with severe consequences are estimated as 1 point. Other violations are rated in a higher share of the points in proportion to the weight of the violation, for example, as "violation of traffic rules at the intersections" is the cause of $8 \%$ of road accidents, and "violation of maneuver rules" is the cause of $16 \%$ of road accidents, the first violation is estimated at 4 points, and the second at 8 points. Further, since the "violation of traffic rules at the intersections" may be the result of two different cases that are fixed by the simulator ("You had to clear the 
road" and "Stop at the intersection is prohibited"), these 4 points are distributed between the causes. If necessary, rounding is performed in order to obtain an integer points. The results of the distribution of penalty points are given in Table 2 . At the same time, the maximum number of points was assigned to violation № 9 which is "ACCIDENT".

Table 2

\section{Recommended penalty points for general errors at the AIS simulator}

\begin{tabular}{|c|c|c|c|c|}
\hline \multirow[b]{2}{*}{ № } & \multirow[b]{2}{*}{ Name of the error } & \multicolumn{3}{|c|}{ Weight of the mistake } \\
\hline & & According to $[8]$ & $\begin{array}{c}\text { Number of } \\
\text { points }\end{array}$ & $\begin{array}{l}\text { Number of } \\
\text { points } \\
\text { according to } \\
\text { the log-scale }\end{array}$ \\
\hline 1. & - "Moving at the roadside" & - & 1 & 1 \\
\hline 2. & - "Moving into the oncoming traffic lane" & $\mathrm{Y} * 16 \%$ & 3 & 2 \\
\hline 3. & - "Failing to stop at a prohibitory traffic sign" & $\mathrm{Y} * 16 \%$ & 3 & 2 \\
\hline 4. & - "Stop at the intersection is prohibited" & $\mathrm{X} * 8 \%$ & 2 & 2 \\
\hline 5. & - "Driving without stop is forbidden" & $\mathrm{Y} * 16 \%$ & 3 & 2 \\
\hline 6. & - "Driving through closed barrier" & - & 1 & 1 \\
\hline 7. & - "You had to clear the road" & $\mathrm{X} * 8 \%$ & 2 & 2 \\
\hline 8. & - "Keep the distance" & $7 \%$ & 4 & 2 \\
\hline 9. & - "Accident!!!" & \#\# & 17 & 4 \\
\hline 10. & - "Blinding by the light of the oncoming vehicle" & - & 1 & 1 \\
\hline 11. & - "Exceeding the speed limit" & $26 \%$ & 16 & 4 \\
\hline 12. & - "Time limits are exceeded" & - & 1 & 1 \\
\hline \multicolumn{5}{|c|}{$\begin{array}{l}\mathrm{X} \text { - coefficient of proportionality which takes into account different kinds of "Violation of traffic rules } \\
\text { at the intersection"; } \\
\text { Y - coefficient of proportionality which takes into account different kinds of "Violation of maneuver } \\
\text { rules"; } \\
\text { "-" - is not fixed among the main } 9 \text { causes; } \\
\text { "\#\#" is a comnlex error that corresnonds to the accident itself }\end{array}$} \\
\hline
\end{tabular}

Taking into account the individual features of mastering the material. It should be noted that the training time with the simulator, in accordance with [10], is only $15 \%$ of the total amount of training time. It is clear that in such a limited time, even using the most perfect simulator, it is impossible to simulate situations that will allow you to check knowledge of all traffic rules, and in case a trainee violates a certain rule, the simulator cannot repeat modelling similar situation until the trainee confidently solves the problem situation. Nevertheless, in the long run, it is advisable to recommend an adaptive course of training, in the first phase of which the AIS simulator fixes typical mistakes of the trainee, and subsequently at the stage of testing and verification increases the number of penalty points for an error if it is repeated.

Thus, the number of penalty points received by the person who underwent the training and was tested on the simulator may be described by the following expression:

$$
S=\sum_{j=1}^{N_{z}} \alpha_{j} \beta_{j} b_{j}+\sum_{j=1}^{N_{s}} \gamma_{j} c_{j},
$$

where $N_{z}$ - the number of types of general errors fixed by the AIS stimulator (in our case, the first group of 12 errors), $N_{s}$ - the number of types of errors of a special nature (the second group of 33 errors), $b_{j}$ and $c_{j}$ - the base price of the error of general and special nature respectively, $\beta_{j}-$ the coefficient that takes into account the complexity of the possible accident (Table 2.), $\alpha_{j}$ and $\gamma_{j}-$ individual weights, which take into account the state of how the material has been learned. 
At the first testing all individual weights are assigned value 1 and in the course of testing the simulated situations that can lead to errors are being fixed, and typical student mistakes are recorded as $j$ numbers. In case such errors are absent, in future tests preference to new situations (routes) is given. However, if there are such mistakes, in the list of future situations, we introduce situations in which they occurred or may occur and the individual weight of the errors increases (recommended interval $1.5<\alpha_{j} ; \gamma_{j}<2.5$ ). This allows adaptive response of AIS simulator to learning capabilities of a trainee. The importance of account for personal driver's performance expressed with physiological indices as well as subjective rating and a specific performance measure is discussed in [15].

\section{CONCLUSIONS AND PROSPECTS OF FURTHER RESEARCH}

The use of AIS in the system of driver training opens up new possibilities for adapting the learning process to the main problems the trainee may encounter in professional activities: increasing the intensity of traffic, changes in the state of roads and other factors are the cause of variations in statistics of accidents with severe consequences that should be considered when choosing accents in the educational process. The analysis of the causes of road accidents with severe consequences allows us to substantially adjust the parameters of the system of evaluation of existing training resources, in order to increase the efficiency of mastering the material. Wider involvement of simulators with elements of AIS improves the quality of students' training without increasing teachers' workload.

Provided that the amount of training time on the simulators is increased, it is expedient to introduce elements of the adaptive AIS response that accounts for individual peculiarities of trainees. One possible approach to this is accounting for repeated errors with correction of penalty points. A prospect of further research is also the justification of the choice of the study route (in terms of complexity) during real driving, taking into account the individual progress of the student's training. More complicated learning algorithms require the use of more complex specialized software and simulators. The proposed model of adaptive driver training is based on linear modification of AIS penalty point function with regard for the severity of driving error consequences, prevalence of recent accidents related to the error and trainees' individual progress.

\section{REFERENCES (TRANSLATED AND TRANSLITERATED)}

[1] O. Saukh. "Competent approach to the training of skilled workers by the profession of" driver of motor vehicles "in the conditions of vocational schools", Innovative technologies in the production and training of specialists in technology, vocational education and services, p.125-130, 2015. [Online]. Available: http://eKhSUIR.kspu.edu/handle/123456789/1357. Accessed on: Feb. 21, 2019. (in Ukrainian)

[2] Y. Krasnik, O. Rimar, T. Popovich. "Substantiation of the effectiveness of the creation of training and training resources for the training of personnel of the Armed Forces on the basis of maximum use of computer technologies", Viys'kovo-tekhnichnyy zbirnyk ASV, № 1(4), p.183-187, 2011. (in Ukrainian)

[3] V. Kostyuk, V. Belen, P. Rusilo. "Substantiation of a rational nomenclature of modern training equipment for the training of specialists in the automobile service in the land forces of the Armed Forces of Ukraine", Viys'kovo-tekhnichnyy zbirnyk ASV, № 1(4), p.177-182, 2011. (in Ukrainian)

[4] K. Shevchenko, V. Gorkun, S. Kozupitsa. "Opportunities for training drivers with the help of modern computer programs and simulator-modeling complexes", Visnyk KNUTD, №3, pp. 39-43, 2011. (in Ukrainian)

[5] Moraes, T. D., Zambroni-de-Souza, P. C., \& Schwartz, Y. (2017). Usages of Simulators During Professional Training for Driving road Transportation. Psicologia: Ciência e Profissão, 37(1), 192-207. (in English) 
[6] Allen, R. W., Park, G. D., Cook, M. L., \& Fiorentino, D. (2007). The effect of driving simulator fidelity on training effectiveness. DSC 2007 North America. (in English)

[7] Bélanger, A., Gagnon, S., \& Stinchcombe, A. (2015). Crash avoidance in response to challenging driving events: The roles of age, serialization, and driving simulator platform. Accident Analysis \& Prevention, 82, 199-212. (in English)

[8] Management of road safety. Accident Statistics in Ukraine. [Online]. Available: http://www.sai.gov.ua/ua/ ua/static/21.htm. Accessed on: Feb. 07, 2016. (in Ukrainian)

[9] Main statistical office in Lviv region. Road accidents and casualties in Lviv region. [Online]. Available: www.lv.ukrstat.gov.ua/ukr/si/year/2010/t089909_52.pdf. Accessed on: Mar. 05, 2019. (in Ukrainian)

[10] Ministry of Education and Science of Ukraine. (Order of the Ministry of Education and Science №802 of 10.07.12). State Standard of Vocational Education and Training DSPT 8322.OI.00.60.24-2012 "The driver of vehicles. Specialization: driving vehicles category" C "(driving the maximum authorized mass of which exceeds $7500 \mathrm{kh}$ (16,500 pounds)". [Online]. Available: https://mon.gov.ua/ua/osvita/profesijno-tehnichnaosvita/derzhavni-standarti-navchalni-plani-ta-programi/zatverdzheni-standarti-profesijno-tehnichnoyi-osviti2006-2016. Accessed on: Mar. 20, 2019. (in Ukrainian)

[11] V. Bilichenko, V. Raziborinsky. "Analysis of approaches to the classification of motor cycles for training drivers". Naukovi notatky. - 2014. Vyp. 46. - P. 29-37. [Online]. Available: http://nbuv.gov.ua/UJRN/Nn_2014_46_6. Accessed on: Feb. 20, 2019. (in Ukrainian)

[12] S. Subbotin. Presentation and processing of knowledge in systems of artificial intelligence and decision making support. Tutorial. Zaporizhzhya: ZNTU, 2008. $341 \mathrm{p}$.

[13] Cabinet of Ministers of Ukraine. Resolution №1306 of 10 October 2001, as amended "About the Rules of the Road". [Online]. Available: https://zakon0.rada.gov.ua/laws/show/1306-2001-\%D0\%BF. Accessed on: Mar. 04, 2019. (in Ukrainian)

[14] A. Kashkanov, O. Hrysyuk. Safety of motor transport. Tutorial. Vinnitsa: VNTU, 2005. 177 p. (in Ukrainian)

[15] Tran, C. C., Yan, S., Habiyaremye, J. L., \& Wei, Y. (2017, December). Predicting driver's work performance in driving simulator based on physiological indices. In International Conference on Intelligent Human Computer Interaction (pp. 150-162). Springer, Cham. (in English)

Text of the article was accepted by Editorial Team 29.05.2019

\title{
АДАПТИВНА ПІДГОТОВКА ВОДІЇВ ІЗ ЗАСТОСУВАННЯМ СИСТЕМ ТРЕНАЖЕРІВ
}

\author{
Кузьменко Руслан Валентинович \\ кандидат технічних наук, заступник начальника кафедри водіння бойових машин та автомобілів \\ Національна академія сухопутних військ імені гетьмана Петра Сагайдачного, м. Львів, Україна \\ ORCID 0000-0003-3452-725X \\ kuru1978@gmail.com
}

\begin{abstract}
Анотація. У статті розкрито окремі аспекти застосування автоматизованих інформаційних систем у процесі професійної підготовки водіїв транспортних засобів у Національній академії сухопутних військ імені гетьмана Петра Сагайдачного. Вказано на важливість інтеграції теоретичної і практичної компонент навчання та на зв'язок результатів навчання із безпекою на дорогах нашої держави. До складу сучасних навчально-тренажерних засобів підготовки водіїв (тренажерів) входять інформаційні програмні компоненти, що дають змогу здійснювати налаштування цих засобів із врахуванням індивідуальних особливостей студента та пріоритетів розгляду проблемних ситуацій у реальних дорожньо-транспортних умовах. Оцінка знань та навичок студента при застосуванні тренажерів здійснюється шляхом аналізу його помилок на типових маршрутах, що моделюють проблемні дорожньо-транспортні ситуації. Основні типи помилок відповідають поширеним причинам дорожньо-транспортних подій (ДТП), стосовно яких є статистика за регіонами та періодами, що дозволяє оперативно реагувати в навчанні на зміну структури ДТП за причинами скоєння упродовж останніх років. Налаштування автоматизованої інформаційної системи здійснює викладач шляхом корекції штрафних балів за кожен тип помилки. При досягненні критичної суми таких балів студент скеровується на перепідготовку теми, що дає змогу забезпечити належний рівень засвоєння матеріалу перед
\end{abstract}


початком занять в умовах реальної дорожньої ситуації. У перспективі при збільшенні частки бюджету навчального часу на навчання на тренажері $\epsilon$ можливим врахування індивідуальних особливостей студентів у засвоєнні матеріалу різних тем та розділів. Це можна реалізувати, вводячи у штрафну функцію підвищені коефіцієнти на помилки, що повторюються. Для цього в роботі запропоновано лінійну за типами модель оцінки сумарного штрафного балу, у якій враховано помилки спеціального та загального характеру, причому для останніх базова ціна помилки пов' язана із часткою ДТП із важкими наслідками. Мультиплікатор індивідуальної ваги помилки дає змогу збільшити ії значення у випадку, якщо цей тип помилки траплявся раніше, а студент ії не врахував.

Ключові слова: автоматизовані інформаційні системи; підготовка водія транспортного засобу; навчально-тренажерні засоби; оцінювання результатів навчання; правила дорожнього руху.

\section{АДАПТИВНАЯ ПОДГОТОВКА ВОДИТЕЛЕЙ С ПРИМЕНЕНИЕМ СИСТЕМ ТРЕНАЖЕРОВ}

\section{Кузьменко Руслан Валентинович}

кандидат технических наук, заместитель начальника кафедры вождения боевых машин и автомобилей Национальная академия сухопутных войск имени гетмана Петра Сагайдачного, г. Львов, Украина ORCID 0000-0003-3452-725X

kuru1978@gmail.com

Аннотация. В статье раскрыто отдельные аспекты применения автоматизированных информационных систем в процессе профессиональной подготовки водителей транспортных средств на примере подготовки курсантов (далее - студентов) в Национальной академии сухопутных войск имени гетмана Петра Сагайдачного. Обращено внимание на важность интеграции теоретической и практической компонент обучения и на связь результатов обучения с безопасностью на дорогах. В состав современных учебно-тренажерных средств подготовки водителей (тренажеров) входят программные компоненты, позволяющие осуществлять настройку этих средств с учетом индивидуальных особенностей студента и приоритетов рассмотрения проблемных ситуаций в реальных дорожно-транспортных условиях. Оценка знаний и навыков студента при применении тренажеров осуществляется путем анализа его ошибок на характерных маршрутах, на которых моделируются проблемные дорожно-транспортные ситуации. Основные типы ошибок соответствуют распространенным причинам дорожно-транспортных происшествий (ДТП), по которым ведется статистика как по регионам так и по периодам, что позволяет во время обучения оперативно реагировать на изменение структуры ДТП по причинам их совершения. Настройку автоматизированной информационной системы осуществляет преподаватель путем коррекции штрафных баллов за каждый тип ошибки. При достижении критической суммы таких баллов студент направляется на повторное изучение темы, что позволяет обеспечить соответствующий уровень усвоения материала перед началом практических занятий в условиях реальной дорожной ситуации. В перспективе при увеличении доли бюджета учебного времени на обучение на тренажере возможен учет индивидуальных особенностей студентов усвоения учебного материала различных тем и разделов. Это можно реализовать, вводя в штрафную функцию повышенные коэффициенты на ошибки, которые повторяются. Для этого в работе предложено линейную, по типам, модель оценки суммарного штрафного балла, в которой учтены ошибки специального и общего характера, причем для последних базовая цена связана с долей ДТП с тяжелыми последствиями. Мультипликатор индивидуального веса ошибки позволяет увеличить ее значение в случае, если этот тип ошибки случался ранее, а студент ее не учел и не сделал надлежащего вывода.

Ключевые слова: автоматизированные информационные системы; подготовка водителя транспортного средства; учебно-тренажерные средства; оценивания результатов обучения; правила дорожного движения.

\section{(cc) EY-NC-SA}

This work is licensed under Creative Commons Attribution-NonCommercial-ShareAlike 4.0 International License. 